- инициатива органов, осуществляющих ОРД, при наличии у них достаточных данных, указывающих на признаки преступления. Это является основанием для возбуждения уголовного дела (ч. 2 ст. 140 УПК).

- выполнение поручения дознавателя, органа дознания, следователя, судебного решения о проведении оперативно-розыскных мероприятий по уголовным делам и материалам проверки сообщений о преступлениях, находящимся в их производстве;

- исполнение требования суда (судьи) о представлении документов по уголовным делам, находящимся в его производстве.

Результаты ОРД, в частности ОРМ «опрос», в соответствии с Инструкцией рекомендуется представлять в виде рапортов или сообщений органов, осуществляющих ОРД.

Если не требуется засекречивание источника информации, то опрос можно легализовать очень просто. Следователь вправе вновь допросить лицо, которому что-либо известно по уголовному делу, составив при этом протокол допроса. А если уголовное дело еще не возбуждено, то можно оформить полученные сведения в объяснение.

\title{
***
}

1. Конституция Российской Федерации (принята всенародным голосованием 12.12.1993) (с учетом поправок, внесенных Законами РФ о поправках к Конституции РФ от 30.12.2008 № 6-ФКЗ, от 30.12.2008 № 7-ФК3, от 05.02.2014 № 2-ФКЗ, от 21.07.2014 № 11-ФКЗ) // Собрание законодательства РФ. - 2014. - № 31. - Ст. 4398.

2. Уголовно-процессуальный кодекс Российской Федерации от 18.12.2001 № 174-Ф3 (ред. от 07.03.2017) (с изм. от 11.05.2017) // Собрание законодательства РФ. - 2001. - № 52 . - ст. 4921.

3. Федеральный закон от 12.08.1995 N 144-Ф3 «Об оперативно-розыскной деятельности» (ред. от 06.07.2016) [Электронный ресурс]: Интернет версия системы «КонсультантПлюс». - Режим доступа: http://www.consultant.ru/document/cons_doc_LAW_7519/

4. Об утверждении Инструкции о порядке представления результатов оперативно-розыскной деятельности дознавателю, органу дознания, следователю, прокурору или в суд: приказ МВД России, ФСБ России, ФСО России, ФТС России, СВР России, ФСИН России, ФСКН России, Минобороны России от 27.09.2013 г. № 776/703/509/507/1820/42/535/398/68. [Электронный ресурс]: Интернет версия системы «КонсультантПлюс». - Режим доступа: http://www.consultant.ru/document/cons_doc_LAW_155629/

5. Маркушин А.Г. Оперативно-розыскная деятельность в раскрытии и расследовании преступлений. - Н. Новгород, 2010. - 317 с.

6. Мищенко Л.В. Об оптимизации процедуры передачи результатов ОРД следователю // Оперативнорозыскная работа: Бюллетень. - 2001. - № 2(161). - С. 72.

\section{Болтышова А.С.}

Исполнение приказа как обстоятельство, исключающее преступность деяния

МГТУ им. Н.Э. Баумана

(Россия, Москва)

doi:10.18411/lj-06-2018-59

idsp: 000001:lj-06-2018-59

\section{Аннотация}

Статья посвящена правовому исследованию понятий и принципов, лежащих в основе взаимоотношений между военнослужащими, среди которых особую значимость приобретают отношения командир-подчиненный и их особенности. Поднимается вопрос о юридической оценке действий подчиненного, получившего незаконный приказ командира, и обосновывается мнение о его законодательной недосказанности.

Ключевые слова: исполнение приказа; незаконный приказ; военная служба; принцип единоначалия; обстоятельства, исключающие преступность деяния. 
Abstract

The article examines the terms and principles on which the relations between the military are based. Notable among them is the relationship between commander and subordinates and their characteristics. The question of legality of actions of the subordinate who received the illegal order is raised. The conclusion is that the law is formulated in a vague way.

Keywords: the execution of orders; unlawful orders; military service; the principle of unity of command; the circumstances excluding criminality of act.

Отношения между военнослужащими урегулированы целым перечнем нормативно-правовых актов, среди которых особое место занимает Устав внутренней службы Вооруженных Сил Российской Федерации (далее УВС ВС РФ). Но вопреки обилию разнообразного по своей специфике военного законодательства, крайне острым, спорным и слабо освещенным остается вопрос об исполнении или неисполнении незаконного приказа, отданного начальником непосредственному подчиненному.

Как прямо указано в УВС ВС РФ, приказ - это распоряжение командира (начальника), обращенное к подчиненному и требующее обязательного выполнения определенных действий, соблюдения тех или иных правил или устанавливающее какойлибо порядок, положение. При этом старшинство определяется воинскими званиями военнослужащих, а принадлежность военнослужащего к категории начальника или подчиненного определяется статьями 35 и 36 УВС ВС РФ.

Сам процесс отдачи и выполнения приказа строится на совокупности заложенных в законодательстве принципов. Так, подчиненный обязан беспрекословно выполнять приказы командира (начальника). Обсуждение (критика) приказа недопустимо, а неисполнение приказа командира (начальника), отданного в установленном порядке, является преступлением против военной службы. Вооруженные силы со времен своего формирования функционируют на базе единоначалия, суть которого заключается в наделении командира (начальника) правом, исходя из всесторонней оценки обстановки, единолично принимать решения, отдавать в установленном порядке соответствующие приказы и обеспечивать их выполнение, а также в возложении на него персональной ответственности перед государством за все стороны жизни и деятельности воинской части, подразделения и каждого военнослужащего.

В то же время командирам (начальникам) запрещено отдавать приказы, не имеющие отношения к исполнению обязанностей военной службы или в противоречии с законодательством РФ. Сам приказ формулируется ясно, кратко и четко без употребления формулировок, допускающих различные толкования. Регламентируя взаимоотношения в сфере военной службы, УВС ВС РФ не содержит упоминания о том, какие действия необходимо предпринять военнослужащему, находящемуся в роли подчиненного и получившему незаконный по форме и/или содержанию приказ. Что в данном случае является правомерным: ослушаться приказа, нарушая принцип единоначалия, и столкнуться с перспективой совершения преступление против военной службы или все же исполнить приказ, нарушающий законодательство РФ, и, тем самым, посягнуть на наиболее ценные общественные отношения?

Очевидно, что положения УВС ВС РФ были установлены, исходя из презумпции законности каждого приказа командира (начальника) и соответствия приказа интересам службы. Однако воинская служба не исключает возможности столкнуться с нарушением данной презумпции.

Глава 8 Уголовного кодекса РФ (далее УК РФ) в качестве обстоятельства, исключающего преступность деяния, наряду с необходимой обороной, крайней необходимостью и т.д., предусматривает исполнение приказа или распоряжения. При этом вся суть являющегося предметом выше обозначенной дискуссии вопроса изложена в законе лаконично и не совсем однозначно. Так, в соответствии с ч. 1 ст. 42 УК РФ не 
является преступлением причинение вреда охраняемым уголовным законом интересам лицом, действующим во исполнение обязательных для него приказа или распоряжения. Уголовную ответственность за причинение такого вреда несет лицо, отдавшее незаконные приказ или распоряжение. Буквальное уяснение данной нормы рассеивает всякие сомнения и разрешает вопрос об исполнении незаконного приказа в качестве положительного. Принцип единоначалия определяется, таким образом, главенствующим, а подчиненный обязан беспрекословно, точно и в срок выполнять приказы командира (начальника). Сначала выполнять и только после этого в случае несогласия обжаловать вышестоящему лицу, как и предписывает УВС ВС РФ.

С тем чтобы избежать столкновения интересов военной службы и обязанностей по соблюдению закона на общих основаниях и, тем самым, пресечь возможность оправдания преступных действий подчиненного, п. 2 ст. 42 УК РФ предусматривает привлечение к уголовной ответственности лица, совершившего умышленное преступление во исполнение заведомо незаконного приказа (распоряжения).

Под заведомо незаконным приказом следует понимать такой приказ, незаконный характер которого был понятен подчиненному в момент его исполнения. Исполнитель приказа, заведомо знающий о незаконности (преступности) приказа и, тем не менее, умышленно его выполняющий, несет уголовную ответственность на общих основаниях.

Исходя из анализа всех терминов и законодательных формулировок, можно вполне обоснованно прийти к следующему выводу: исполнение подчиненным приказа командира (начальника), незаконность которого не была ему очевидна, не должно влечь уголовную ответственность за вред, причиненный охраняемым законом интересам во исполнение такого приказа. И наоборот: уголовная ответственность наступает для подчиненного в случае, когда он осознает очевидную незаконность приказа, прежде всего, по содержанию. Тот факт, что подчиненный выполнял, хотя и заведомо незаконный, но все-таки приказ своего командира (начальника), признается смягчающим обстоятельством (п. п. «е» и «ж» ч. 1 ст. 61 УК РФ).

Лицо, отказавшееся выполнять заведомо незаконные приказ или распоряжение, не может быть привлечено за это к ответственности.Вместе с тем, в среде военнослужащих, где ключевым принципом является беспрекословное подчинение вышестоящему по званию и безукоризненное следование дисциплине, оспорить приказ командира (начальника) осмелится далеко не каждый подчиненный. И в этом есть рациональное зерно, так как функционирование вооруженных сил зайдет в тупик, если разрешить нижестоящим по званию допускать излишние комментарии и сомнения, особенно в вопросах, полной информацией о которых располагает исключительно старшее командование или в ситуации вооруженного конфликта.

Законность действий военнослужащего, на которого распространяется незаконный приказ, определяется судом с учетом всех обстоятельств дела по правилам об оценке действий обороняющегося от посягательств, не опасных для жизни. Подчиненный должен действовать таким образом, чтобы его действиями был причинен вред меньше того вреда, который наступил бы, если бы он действовал иначе.

Таким образом, окончательная квалификация поведения подчиненного в случае получения им незаконного приказа вышестоящего лица напрямую зависит от судейского усмотрения, что в совокупности со спецификой отношений военнослужащих и сложностью распознавания законности полученного приказа может спровоцировать правоприменительные проблемы.

$$
\text { *** }
$$

1. Комментарий к Уголовному кодексу РФ / под ред. В.М. Лебедева. М.: Юрайт. 2014. 1077 с.

2. Об утверждении общевоинских уставов Вооруженных Сил Российской Федерации: Указ Президента РФ 10.11.2007 N 1495 (ред. от 22.01.2018) // Собрание законодательства Российской Федерации (СЗРФ). 2007. N 47 (1 ч.). Ст. 5749. 
3. Тиханова Н.Е. Проблемные аспекты применения оружия в состоянии необходимой обороны // Вестник Воронежского государственного университета. Серия: Право. 2018. N 1 (32). С. 186-190.

4. Тиханова Н.Е. Условия правомерности необходимой обороны от опасных для жизни посягательств // Известия Тульского государственного университета. Экономические и юридические науки. 2016. N 2-2. С. 199-203.

5. Уголовный кодекс РФ: Федеральный закон от 13.06.1996 г. № 63-Ф3 (ред. от 30.12. 2015) // Собрание законодательства Российской Федерации (СЗРФ). 1996. N 25. Ст. 2954.

6. Ушаков Е.Ю. К вопросу о юридической конструкции, связанной с уголовно-правовой оценкой исполнения приказа или распоряжения в системе обстоятельств, исключающих преступность деяния // Территория новых возможностей. Вестник Владивостокского государственного университета экономики и сервиса . 2014. N 4 (27). С. 45-51.

Водяницкий В.А.

\section{Правозащитная деятельность должностных лиц правоохранительных органов}

doi:10.18411/lj-06-2018-60

idsp: 000001:lj-06-2018-60

Необходимая оборона это прежде всего правомерная защита от общественно опасного посягательства на охраняемые уголовным законодательством интересы граждан и государства, путем причинения посягающему вреда при соблюдении необходимых условий.

Необходимая оборона субъективное право человека, то есть он может обороняться, но может и не воспользоваться этим правом. При этом, не использование права на необходимую оборону, может повлечь только моральное осуждение со стороны общества.

Но существует отдельная категория людей, в силу закона или в силу их служебного положения эти лица обязаны заниматься охраной общественного порядка, пресекать совершение преступлений и осуществлять спасение людей и их имущество.

Но правомерные действия этих лиц, находящихся при исполнении своих служебных обязанностей, даже если они сопряжены с причинением вреда или угрозой причинения, состояния необходимой обороны не образуют (применение в установленных законом случаях силы сотрудниками правоохранительных органов при обеспечении общественной безопасности и общественного порядка и др.).

Прежде всего к этим должностным лицам относятся сотрудники полиции, деятельность которых осуществляется по следующим направлениям:

1) защита личности, общества, государства от противоправных посягательств; 2)предупреждение и пресечение преступлений и административных правонарушений; 3) выявление и раскрытие преступлений, производство дознания по уголовным делам; 4) розыск лиц; 5) производство по делам об административных правонарушениях, исполнение административных наказаний; 6) обеспечение правопорядка в общественных местах; 7) обеспечение безопасности дорожного движения; 8) государственная защита потерпевших, свидетелей и иных- участников уголовного судопроизводства, судей, прокуроров, следователей, должностных лиц правоохранительных и контролирующих органов, а также других защищаемых лиц; 9) осуществление экспертно-криминалистической деятельности.

В Российской Федерации создана ведомственная охрана. Ведомственная охрана совокупность создаваемых имеющими право на создание ведомственной охраны федеральными государственными органами и организациями органов управления, сил и средств для защиты охраняемых объектов от противоправных посягательств. В соответствии с Федеральным законом «О ведомственной охране» основными задачами этого органа является: защита охраняемых объектов от противоправных посягательств; обеспечение на охраняемых объектах пропускного и внутриобъектового режимов; 